\title{
EFEKTIFITAS KOMUNIKASI ORANG TUA TERHADAP KEPRIBADIAN INTRAPERSONAL ANAK
}

\author{
Tri Endang Jatmikowati \\ Universitas Muhammadiyah Jember \\ Email: triendang@unmuhjember.ac.id
}

\begin{abstract}
ABSTRAK
Pentingnya peran orang tua dalam pengembangan potensi anak bisa dimulai sejak anak masih usia dini. Penelitian ini bertujuan untuk mengetahui sejauh mana hubungan antara efektifitas komunikasi orang tua terhadap kepribadian intrapersonal anak. Subyek penelitian adalah siswa kelompok B1 / usia 5-6 tahun Sekolah PAUD Terpadu Aisyiyah Kaliwates Kabupaten Jember sebanyak 18 orang, pengumpulan data dilakukan dengan teknik observasi dan angket. Data dianalisis dengan menggunakan product moment dari Karl Pearson. Hasil penelitian dengan koefisien korelasi menunjukkan 0,900, dengan taraf kesesatan 5\% =0,514, hal ini menunjukkan bahwa terdapat korelasi searah yang positif antara kedua variabel tersebut, artinya tingginya nilai komunikasi efektif orang tua akan diikuti pula oleh tingginya nilai atau tingkat kecerdasan intrapersonal anak. Melalui pembiasaan dan kesadaran orang tua untuk melakukan komunikasi yang efektif kepada anak, mampu membantu anak untuk mengembangkan kemapuan intrapersonal.
\end{abstract}

Kata kunci: anak, kepribadian intrapersonal, komunikasi efektif, orang tua

\begin{abstract}
Parents have very crucial roles in building a child's potentials and it is urged to do in the early age. This study aimed to find out the correlation between the effectivity of communication the parents have with their children toward the children's intrapersonal intelligence. The subjects of the study were 18 students of early childhood education ages 5-6 at PAUD Terpadu Aisyiyah Kaliwates Jember. The data were gatherd using observation and questionnaire. Karl Pearson's product moment was employed to analyze the data. The results of the study revealed thecorrelation coefficient of 0.900 and standart error of $5 \%=0.514$. This means it has positive correlation between the parents' effectiveness of communication toward the child's intrapersonal intelligence. In other words, the more effective the parents' communication, the better the child' intrapersonal intelligence is.
\end{abstract}

Keywords: children, effective communication, intrapersonal intelligence, parents

\section{PENDAHULUAN}

Masa anak usia dini merupakan

salah satu periode yang sangat penting

dalam perkembangan kecerdasan anak

karena periode ini merupakan tahap

perkembangan kritis dan juga strategis

dalam proses tumbuh kembang anak.
Periode ini merupakan periode yang kondusif guna merangsang berbagai kemampuan anak yang meliputi kemampuan fisik, kognisi, bahasa dan sosial emosional. Keluarga yang harmonis sangat memungkinkan 
terciptanya lingkungan yang kondusif bagi perkembangan kepribadian anak. Hal ini akan terwujud manakala ada komunikasi yang efektif antar anggota keluarga terutama antara orangtua dan anak (Laily\& Matulessy, 2004). Pada periode ini, lingkungan yang paling berpengaruh terhadap kepribadian anak adalah lingkungan keluarga. Keluarga merupakan lembaga pendidikan pertama yang dikenal oleh anak dan di dalamnya ada orang tua yang merupakan pendidik yang pertama dan utama bagi mereka.

Perlu diingat, anak bukanlah sebuah obyek atau benda yang bisa dibentuk dengan cara yang otoriter. Namun pada kenyatannnya, sekarang ini masih banyak orang tua yang lebih suka mencetak anak agar bisa menjadi patuh dan bukan menjadi mandiri. Memang anak menjadi penurut, mau mengerjakan perintah dan keinginan orang tua, akan tetapi itu semua hal yang dia lakukan bukanlah keinginannya sendiri. Susanto ( 2011 ) menyatakan bahwa orang tua yang berlaku otoriter dan serba mengatur akan menjadikan anaknya terkekang kebebasannya, dan sekaligus dapat menghambat kebebasan anak dalam berekspresi, mengembangkan potensi dan membatasi ruang gerak belajarnya yang pada akhirnya anak akan menjadi tidak mandiri, penakut, serba ragu dan kurang inisiatif.

Di lembaga Pendidikan Anak Usia Dini (PAUD) sering dijumpai anak yang tidak punya keberanian untuk mengungkapkan keinginannya baik pada teman sebayanya maupun pada guru-guru pengasuhnya. Mereka lebih pasif ketika bermain dengan teman-teman sebayanya. Selain itu, mereka cenderung tidak mampu menyelesaikan masalah yang dihadapi dan lebih banyak bergantung pada teman-temannya. Anak-anak tersebut juga tidak memiliki inisiatif untuk memulai suatu tindakan atau aktifitas sehingga mudah dikendalikan oleh teman-temannya, apapun yang akan dia lakukan selalu menunggu perintah dari orang lain.

Dalam usaha kita sebagai orang tua agar anak-anak kita menjadi generasi yang inisiatif dan mandiri, diantaranya bisa dipupuk melalui adanya hubungan yang harmonis antara anak dan orang tua. Hal tersebut 
dipandang penting karena keluarga adalah lingkungan pertama yang dikenal oleh anak sebelum mereka memasuki lingkungan yang lebih besar, yaitu lingkungan sekolah dan masyarakat. Melalui hubungan yang harmonis antara orang tua dan anak, akan mendorong anak untuk bisa menjadi individu yang inisiatif dan mandiri di kemudian hari. Salah satu cara yang bisa ditepuh guna mewujudkan hubungan harmonis tersebut adalah melalui komunikasi.

Komunikasi antara orang tua dan anak merupakan proses membangun hubungan antara orang tua dan anak, baik secara verbal maupun non verbal yang berlangsung dalam kehidupan sehari - hari di lingkungan keluarga. Di dalam keluarga perlu adanya hubungan yang harmonis antara orang tua dan anak. Hal ini bisa terbangun melalui komunikasi yang efektif. Komunikasi orang tua dan anak dapat dikatakan efektif manakala diantara keduanya mempunyai hubungan yang dekat, saling menyukai, memahami dan terbuka sehingga komunikasi di antara keduanya berlangsung menyenangkan sehingga tumbuh sikap saling mempercayai satu sama lain. Komunikasi yang dilandasi kepercayaan dan keterbukaan akan memudahkan anak untuk menerima pesan apapun yang disampaikan oleh orang tua. Orang tua yang bijak ialah orang tua yang mampu memberikan jawaban yang baik bagi anak-anaknya serta senantiasa melayani pertanyaan anak walaupun terkadang pertanyaanpertanyaan tersebut dianggap kurang atau bahkan tidak logis.

Dalam usahanya menjadi orang tua yang bijak, dalam keluarga perlu adanya saling pengertian antar semua anggota keluarga. Untuk itu diperlukan sikap yang demokratis sehingga keinginan dan pemikiran seluruh anggota kekuarga bisa diungkapkan dengan tanpa adanya rasa ketakutan atau keterpksaan. Dalam keluarga yang demokratis walaupun orang tua mempunyai otoritas penuh dalam memberikan stimulus dan layanan pendidikan pada anak, tetapi anak masih diberi kesempatan untuk mencetuskan keinginannya, sehingga mereka tetap merasa dihormati dan dihargai. 
Komunikasi orang tua dengan anak bisa dilakukan dengan dua cara yaitu komunikasi satu arah dan dua arah. Melalui komunikasi satu arah, orang tua bisa menhampaikan pesanpesan bijak kepada anak. Namun perlu diingat bahwa pesan-pesan tersebut haruslah yang bersifat universal dan tidak menghakimi anak. Selanjutnya diteruskan dengan komunikasi dua arah yang disertai dengan pemahaman bersama terhadap suatu hal menyebabkan kedua belah pihak; baik orang tua maupun anak bisa saling menyampaikan pemikiran, perasaan, informasi, ataupun nasehat, sehingga menimbulkan kesenangan yang berpengaruh pada sikap positif dalam menjalin hubungan. Komunikasi yang efektif ini terbangun berkat adanya keterbukaan, dukungan, empati, dan kesamaan persepsi antara orang tua dan anak. Menurut Edwin (Ronald, 2006) bahwasanya tidak banyak orang tua yang percaya kepada anak-anaknya untuk bisa menentukan sendiri keputusannya. Hal tersebut bisa menghambat anak untuk bisa mandiri dalam kehidupannya kelak. Di sisi lain seorang anak akan merasa bangga apabila dia mampu atau bisa melakukan suatu pekerjaan yang berarti bagi orang lain. Hal ini perlu senantiasa dibangun dan dipupuk sehingga mampu menjadi pendorong bagi anak untuk menjadi insan yang selalu optimis dalam kehidupannya. Komunikasi antara orang tua dan anak dapat dilakukan dengan cara mendengarkan apa saja yang diutarakan oleh anak baik itu berupa cerita, kesulitan-kesulitan atau masalah yang dia hadapi ataupun pertanyaanpertanyaan tentang hal-hal yang tidak atau belum mereka ketahui. Orang tua perlu mendorong anak untuk berani mengungkapkan ide-ide atau gagasannya terhadap suatu hal. Sesibuk apapun orang tua, mereka harus mampu memberikan waktu khusus bagi anak-anaknya untuk membina hubungan yang akrab dan harmonis dengan anak-anak mereka. Tindakan yang demikian mampu menjembatani pengembangan kecerdasan intrapersonal anak.

Kecerdasan intrapersonal mencakup kemampuan mawas diri (memahami kelemahan dan kelebihan diri), kepekaan akan suasana hati 
(inner mood), tujuan diri, motivasi, temperamen dan kecenderungan serta kapasitas untuk mendisiplinkan diri, memahami diri sendiri dan self esteem atau kepekaan diri. Dengan kecerdasan intrapersonalnya seseorang mampu memahami kekuatan dan kelemahan dalam dirinya, memahami keinginannya, memiliki rasa percaya diri yang tinggi, dan prinsip yang kuat untuk menjaga perasaannya (Prasojo, 2005). Dengan kecerdasan ini anak memiliki kemampuan untuk mengintrospeksi kesalahan dan memotivasi diri sendiri.

Individu dengan kecerdasan ini memiliki rasa percaya diri yang tinggi serta senang bekerja berdasarkan program sendiri dan melakukannya sendiri. Dia juga bisa memecahkan berbagai masalah dan mengatur hidupnya sendiri dengan baik. Gardner menyatakan bahwa kecerdasan intrapersonal merupakan kemampuan mengenal diri sendiri yang digunakan sebagai model secara teliti dalam kehidupan secara efektif (Goleman, 1999). Seorang anak dengan kecerdasan intrapersonal yang tinggi akan tetap teguh dan tidak mudah terpengaruh oleh orang lain dalam memahami hobinya, sehingga ia berani menjadi berbeda dengan teman sebayanya, karena didukung kepercayaan diri yang kuat.

Manakala orang tua memberikan kesempatan pada anak melalui komunikasi yang efektif, kecerdasan intrapersonal yang dimiliki dapat membentuk karakter anak, serta mampu menanamkan nilai positif dalam diri anak tersebut seperti rasa percaya diri, berfikir mandiri, rasa empati dan konsep diri yang positif. Hurlock (1993) mengemukakan betapa pentingnya hubungan yang baik antara anak dan orang tua dalam keluarga. Namun yang paling penting lagi adalah bagaimana sikap orang tua dalam menilai penampilan, kemampuan, prestasi anak, karena hal tersebut akan sangat berpengaruh terhadap konsep anak akan dirinya.

Pada masa usia dini anak mulai belajar mengungkapkan keinginannya dan anak juga paham bahwa tidak semua keinginan tersebut bisa terpenuhi karena berbenturan dengan kepentingan orang lain. Orang tua yang bijaksana akan bersikap realistis 
terhadap kemampuan anak, sehingga anak memperoleh kesempatan yang wajar untuk meraih kesuksesan.

Komunikasi yang dibangun secara positif sejak usia dini mampu mengembangkan rasa percaya diri, membangun konsep diri yang positif, serta dapat membantu anak dalam menjalin hubungan dengan teman sebayanya. Pada usia 2-6 tahun pada masa ini, anak belajar untuk menjaga diri, belajar mandiri dan sudah siap bersekolah serta suka bermain dengan teman sebayanya (Santrock, 1995:22).

\section{METODE PENELITIAN}

Kajian ini menggunakan jenis penelitian korelasional. Berikut ini adalah bagan untuk menjelaskan hubungan kedua variabel dalam penelitian ini adalah :

\begin{tabular}{|c|c|}
\hline Variabel x & Variabel y \\
\hline Komunikasi & Kecerdasan \\
\hline
\end{tabular}

Penelitian dilaksanakan di

PAUD Terpadu Aisyiyah Kaliwates. Subyek penelitian adalah siswa kelompok B1 / usia 5-6 tahun sebanyak 18 orang.

Untuk memperoleh data empirik yang diperlukan dalam penelitian ini menggunakan:

a. Metode Observasi

Observasi dilakukan untuk mengumpulkan data penelitian dengan cara mengamati setiap kejadian yang sedang berlangsung dan mencatatnya sesuai dengan pedoman observasi yang sudah disiapkan. Pedoman tersebut berisi hal-hal yang berkaitan dengan aktifitas yang mencerminkan kecerdasan intrapersonal anak.

b. Metode Angket

Angket termasuk jenis kuisioner dengan pertanyaan tertutup, dimana jawaban dalam kuisioner terikat pada sejumlah jawaban yang sudah tersedia. Angket digunakan untuk memperoleh data dari orang tua tentang bagaimana orang tua berkomunikasi dengan anak dalam keluarga.

Dalam penelitian ini, untuk menguji instrument penelitian digunakan validitas konstruk, dimana instrumen divalidasi oleh pakar pendidikan dari Dosen FKIP 
Universitas Muhammadiyah Jember. Dari uji validitas menunjukkan bahwa instrumen penelitian dinyatakan valid untuk variabel $\mathrm{x}$ maupun variabel $\mathrm{y}$ dinyatakan valid.

Untuk menguji reliabilitas instrumen penelitian digunakan Alpha Cronbach, karena pada tiap-tiap indikator terdiri dari tiga pilihan yang berskala 1-3. Setelah dilakukan uji reliabilitas instrumen penelitian pada orang tua siswa dan siswa kelompok B2 Sekolah PAUD Terpadu Aisyiyah Kaliwates, diperoleh hasil sebagai berikut; komunikasi orang tua 0,839, sedangkan untuk variabel kecerdasan intrapersonal diperoleh 0,921. Dari hasil tersebut menunjukkan bahwa instrumen penelitian dinyatakan memiliki reliabilitas yang tinggi

Analisa data menggunakan rumus Product Moment dengan taraf kesesatan 5\% dengan dikonsultasikan pada Tabel nilai-nilai $r$ Product Moment.

\section{HASIL}

Hasil penelitian menunjukkan bahwa hipotesis yang berbunyi ada hubungan yang positif antara komunikasi efektif orang tua dengan kecerdasan intrapersonal anak adalah terbukti. Dengan koefisien korelasi sebesar 0,900, dengan taraf kesesatan $5 \%=0,514$, hal ini menunjukkan bahwa terdapat korelasi searah yang positif antara kedua variabel tersebut, artinya tingginya nilai komunikasi efektif orang tua akan diikuti pula oleh tingginya nilai atau tingkat kecerdasan intrapersonal anak.

\section{PEMBAHASAN}

Komunikasi yang dibangun secara efektif oleh orang tua terhadap anak mampu membangun keberanian anak untuk mengambil satu keputusan. Sejak kecil anak perlu diberi kesempatan untuk mengambil keputusan, memilih dan mengerjakan segala sesuatunya secara utuh. Anak diberikan kesempatan untuk memberi saran, belajar untuk mendengarkan orang lain dan bertanggung jawab atas yang dia kerjakan. Hal serupa ditemukan di PAUD Terpadu Aisyiyah Kaliwates, di sini anak dibiasakan untuk membersihkan sendiri ruang makan bersama, meletakkan sepatu dan tas sekolah pada rak yang sudah 
disediakan dan juga memakai sepatu serta mengambil tas sendiri pada saat pulang sekolah. Dengan membiasakan anak-anak melakukan rutinitas tersebut diharapkan mereka bisa belajar untuk melakukan segalanya sendiri dan bertanggung jawab atas barang-barang mereka sendiri.

Sebagai tindak lanjut atas rutinitas yang sudah dilakukan di sekolah, di rumah juga perlu dibiasakan untuk melakukan hal yang sama. Hal tersebut sejalan dengan apa yang diutarakan oleh Susanto ( 2011 ) bahwa di rumah anak oleh orang tua harus dilatih untuk mandiri melakukan kebutuhan sehari-hari misalnya makan, minum, buang air kecil dan besar serta berpakaian. Apabila anak mampu melakukan sendiri pekerjaannya, anak akan merasa bangga. Bukanlah hal yang mudah untuk membiasakan anakanak melakukan segala hal sendiri, diperlukan adanya komunikasi yang tepat antara orang tua dan anak untuk mewujudkannya.

Sebagaimana dikemukakan Edwin (Ronald, 2006) tidak banyak orang tua yang mau memberikan kesempatan pada anak-anaknya untuk mengambil keputusan sendiri. Tanpa disadari para orang tua tersebut sering melakukan komunikasi yang negatif dengan anak-anaknya. Kebanyakan anak merasa komunikasi yang dilakukan orang tua mereka berisi keluhan, perintah, kritik, peringatan dan kata-kata yang bisa menghilangkan keberanian anak.

Sebagai orang tua seharusnya berusaha untuk bisa menghargai pilihan anak, walaupun belum sempurna seperti yang diharapkan. Selain itu, sebagi orang tua yang bijak, orang tua bisa mengkomunikasikan harapan-harapan yang realistis pada anak, yang sesuai dengan kemampuan anak sehingga anak memperoleh kesempatan yang wajar untuk meraih kesuksesan, dan dengan demikian bisa mendorong konsep diri positif pada anak.

Darajat (2007) mengungkapkan bahwa seseorang yang sering gagal dalam hidupnya, maka dia cenderung lebih mudah putus asa, kurang percaya diri dan takut menghadapi kegagalan. Hal yang demikian tentu akan menimbulkan masalah besar bahkan goncangan jiwa pada anak. Adanya 
goncangan pada jiwa anak tersebut bisa menhambat perkembangan kemampuan intrepersonal anak yang bisa menimbulkan pengaruh negatif terhadap kepbibadian anak. Sebaliknya, suasana hati yang menyenangkan bisa menambah kemampuan berfikir anak menjadi fleksibel; baik secara intelektual maupun intrapersonal.

Anak yang pada masa usia dini mampu menahan diri menghadapi permasalahan, pada akhirnya di masa remaja akan lebih cakap secara sosial, tegas, mampu menghadapi kekecewaan, tidak mudah menyerah, memiliki rasa percaya diri yang tinggi serta mampu mengatasi masalah guna mewujudkan keinginannya. Individu yang optimis seperti ini akan menganggap bahwa setiap kegagalan yang dihadapi merupakan tantangan dalam meraih keberhasilan dimasa mendatang. Optimisme samacam ini bisa membentuk generasi anak yang memiliki kecerdasan sehat.

Ciri-ciri anak yang memiliki kepribadian yang sehat menurut Hurlock diantaranya a) anak mampu secara realistik menilai diri baik kelebihan dan kelemahan yang ada pada dirinya, b) mampu menghadapi kondisi kehidupannya secara wajar, c) mampu merespon keberhasilan dan kegagalannya dengan cara yang tidak berlebihan, d) mampu bertanggung jawab terhadap tugasnya, f) memiliki tujuan yang didasari pertimbanganpertimbangan yang matang, g) mampu berpartisipasi aktif dalam lingkungan sosialnya, dan h) memiliki falsafah hidup yang jelas (Yusuf, 2011).

Agar bisa mendidik anak menjadi generasi yang memiliki kecerdasan sehat, orang tua hendaklan mendidik anak-anaknya denga lemah lembut dan penuh kasih sayang. Dengan kelembutan dan kasih sayang mampu mengantarkan anak untuk merasa lebih dihargai dan diakui keberadaanya. Suasana yang demikian bisa dijumpai pada keluarga yang pola pengasuhan otoritatif ( outhoritative parenting). Alfon Pusunguala (2015) menambahkan bahwa komuniksi orang tua dan anak dalam membentuk karakter lebih efektif melalui komunikasi demokratis dari pada pola otoriter secara faceto face. Model ini mampu mendorong anak untuk 
mandiri dalam batas-batas tertentu dimana orang tua masih otoritas terhadap apa saja yang hendaknya dilakukan dan tidak dilakukan oleh anak, namun memberikan anak kesempatan untuk menyampaikan pendapatnya. Setyowati (2005) menyatakan pola komunikasi demokratis dalam keluarga antara orang tua dan anak berpengaruh pada proses perkembangan emosi anak seperti pemahaman tentang perasaan dirinya dan perasaan orang lain. Melalui musyawarah verbal antara orang tua dan anak mampu memberikan kehangatan serta kasih sayang diantara keduanya. Selain itu, pola pengasuhan semacam ini mampu mengembangkan kompetensi sosial anak. Sebagaimana Sari dkk (2010) menyatakan bahwa komunikasi verbal dan non verbal dalam keluarga mampu membantu anak berkembang secara positif.

Sejak usia dini, anak sudah harus dikenalkan tentang bagaimana mengontrol diri, memahami nilai kepercayaan diri, memiliki sikap dan prilaku kreatif, kemampuan berkomunikasi, bersosialisasi, berfikir kritis serta kemampuan memecahkan masalah dalam kehidupannya. Hal tersebut sesuai dengan apa yang dikemukakan Susanto (2011) bahwa apabila anak usia 5 tahun diberi kesempatan untuk bereksperimen dan orang tua mempersiapkan waktu untuk menjawab pertanyaan-pertanyaan anak, maka anak akan mempunyai inisiatif dalam menyelesaikan masalah yang dihadapi. Namun sebaliknya, apabila orang tua selalu menghalangi serta menganggap kegiatan yang dilakukan anak tidak ada nilainya, maka anak akan merasa rendah diri dan akan selalu bergantung kepada orang lain. Parke \& Buriel mengemukakan pendapat tentang peran orang tua. Peran tersebut meliputi tiga hal penting, yang pertama, orang tua sebagi partner atau rekan interaktif, orang tua sebagai instruktur dan peran orang tua sebagai penyedia aktivitas bagi pertumbuhan dan perkambangan anak (Brooks, 2011). Dalam perannya sebagai rekan atau partnet interaktif, orang tua harus bisa berperan ganda sebagi orang tua, teman atau sahabat bagi anak. Sehingga si anak bisa merasa nyaman 
dalam berinteraksi. Peran instruktur maksudnya orang tua bisa menjadi contoh atau guide pada saat anak memerlukan bantuan dalam melakukan suatu aktiftas. Peran yang terakhir, yaitu orang tua sabagai penyedia aktivitas tumbuh kembang anak. Sebagai orang tua diharapkan mampu anak, misalnya dengan menyediakan permainan dan bahan dan media belajar yang sesuai dengan perkembangan fisik maupun mental anak. Dengan memahami dan melakukan peran-peren tersebut, orang tua bisa dengan maksimal mendukung dan mendorong tumbuh kembang anak sehingga kelak menjadi individu yang mandiri.

Dorong anak untuk berani menetapkan sendiri target-target yang ingin diraihnya, tidaklah tepat orang tua memaksa anak, orang tua cukup memberikan motivasi kepada anak untuk mampu mengatasi masalahnya sendiri. Orang tua yang selalu melibatkan anak dalam menegakkan peraturan tentang boleh atau tidaknya melalukan sesuatu, mampu melatih anak untuk terbiasa berfikir dengan bijak sebelum bertindak yang merupakan salah satu cirri penting kecerdasan intrapersonal. Namun sebaliknya, jika anak tidak pernah dilibatkan dalam membuat peraturan, dan hanya ditegur karena kesalahankesalahannya, mereka cenderung tidak mampu untuk berkembang cara berfikirnya, lebih parah lagi mereka tidak mampu mengambil keputusan karena selalu dihantui rasa takut untuk melakukan kesalahan.

Melibatkan anak dalam memutuskan hal-hal yang sederhana merupakan salah satu cara membangun komuniksai yang efektif antara orang tua dan anak. Selain itu ada sejumlah hal-hal yang penting untuk mewujudkannya. Pertama, orang tua harus mampu mengenali anak dengan baik sesuai dengan karakter si anak. Kedua, orang tua harus bisa menghargai perilaku anak. Ketiga, orang tua melibatkan anak dalam berbagai aktivitas, termasuk dalam mengabil keputusan. Keempat, orang tua harus mampu menyediakan waktu untuk bisa dekat dengan anak. Selanjutnya, yang kelima, orang tua harus mampu menyediakan waktu khusus bagi putra-putrinya walapun 
dalam kondisi yang sibuk. Keenam, orang tua sebaiknya mengajarkan kedisiplinan kepada anak sejak usia dini. Ketujuh, orang tua harus mampu menjadi panutan bagi anak, baik perilaku, sikap, maupun tutur katanya. Kedelapan, orang tua harus mampu mengungkapkan rasa kasih saying kepada anak melalui tindakan; pelukan, belaian, ciuman dan senyuman. Hal penting berikutnya, yang ke sembilan adalah orang tua harus mampu membangun komunikasi yang tepat dengan kontak mata ketika sedang berbicara dengan si anak. Yang terakhir dan tak kalah penting adalah orang tua mau dan mampu memilih saaat yang tepat dalam menyelesaikan suatu masalah, yaitu menunggu saat yang tenang ( Nugraha dkk, 2015 ).

Anak sebagai generasi yang siap dengan segala tantangan butuh dukungan dari lingkungan yang kondusif, yaitu lingkungan dimana orang tua terbiasa melakukan komunikasi dengan suasana penuh kasih sayang, mau menerima anak apa adanya, menghargai potensi anak yang unik dan juga merangsang anak untuk berani melakukan sendiri segala sesuatu yang mampu menghantarkan mereka menjadi individu yang mandiri dan unggul dimasa yang akan datang.

Orang tua perlu menyadari bahwa prestasi akademik di sekolah belum bisa menjamin keberhasilan anak di masa depan tanpa didukung oleh kepribadian yang memiliki kemampuan memahami diri secara obyektif terkait dengan kelebihan dan kelemahan yang ada pada dirinya. Dengan membiasakan saling menghargai antara orang tua dan anak melalui komunikasi yang terbuka, dengan jalan menjadi pendengar yang baik manakala anak menceritakan pengalaman - pengalamannya ketika meraka berinteraksi dengan teman sebayanya disekolah atau dilingkungan sekitarnya, baik pengalaman menyenangkan ataupun mengecewakan sebaiknya orang tua tidak menginterupsi pembicaraan anak. Ketika orang tua bersedia mendengarkan keluh kesahnya, anak akan semakin antusias dalam mengungkapkan pikiran dan perasaannya apalagi dibarengi dengan belaian dan sentuhan hangat. Hal tersebut akan mendorong mereka 
tumbuh menjadi individu dewasa yang memiliki penilaian yang baik atas dirinya sendiri dan juga pada orang lain.

\section{SIMPULAN}

Semakin efektif komunikasi yang dilakukan oleh orang tua kepada anak-anaknya, maka semakin berkembang pula kecerdasan intrapersonal anak. Artinya berkualitas dan tidaknya orang tua laki-laki maupun perempuan melakukan komunikasi dengan anak akan menentukan baik buruknya tingkat kecerdasan intrapersonal anak.

Komunikasi antara anak dan orang tua yang berlangsung terbuka membuat anak merasa diterima. Anak mempunyai keberanian untuk menentukan pilihannya sendiri sedangkan orang tua terbiasa untuk mengkomunikasikan harapan yang realistis sesuai dengan kemampuan anak-ankanya, dengan demikian, konsep diri yang positif pada anak akan terbangun dengan sendirinya.

Bila komunikasi orang tua
tanpa didasari
penghargaan dan

melainkan hanya didasari penghinaan dan kecurigaan terhadap anak maka kemandirian anak semakin rendah, sehingga anak akan mengalami kesulitan untuk memahami kelebihan dan kelemahan yang ada pada dirinya.

Anak perlu didorong untuk menentukan sendiri target-target yang ingin diraihnya. Orang tua cukup memberikan motivasi kepada anak dalam mengatasi masalahnya.

Libatkan anak dalam menegakkan aturan, tidak hanya membuat larangan tetapi anak perlu juga mengetahui dasar alasannya. Kondisi yang demikian akan membiasakan anak untuk berfikir bijak sebelum bertindak dan kecerdasan intrapersonalnya akan semakin terasah.

\section{DAFTAR PUSTAKA}

Brooks, Jane. 2011. The Process of parenting, Yogyakarta. Pustaka Pelajar

Darajad.Z.Juni 2005. Ayah Ibu, Nikahkanlah Aku. Surabaya: Al Fatah

Effendy, Onong U. 2000. Ilmu Teori dan Filsafat Komunikasi. Bandung: Citra Aditya Bakti Goleman, Daniel. 1999. Kecerdasan 
Emosional. Jakarta: Gramedia

Pustaka Utama

Gleason, Mary Ellen. 2011. Intrapersonal Intelligence Strategies in the Developmental Writing Classroom. The Journal of Virginia Community Colleges Volume 16. No 1. 2011

Hurlock, Elizabeth B. 1993. Psikologi

Perkembangan. Jakarta: Erlangga

Laily, N \& Matulessy, A. 2004. Pola Komunikasi Masalah Seksual Antara Orangtua dan Anak. Jurnal Psikologi Vol 19 No 2: 194-205

Musfiroh, Tadkiroatun. 2014 Pengembangan Kecerdasan Majemuk. Banten: Universitas Terbuka

Nugraha, Ali dkk, 2015. Program Pelibatan Orang Tua dan Masyarakat. Banten.

Universitas Terbuka

Pusungula, Alfon dkk. 2015. Pola Komunikasi Keluarga dalam Membentuk Karakter Anak di Kelurahan Beo Talaud. E- journal “Acta Diurna” Volume

IV No 52015

Ronald, 2006. Peran Orang Tua Meningkatkan Kualitas Hidup, Mendidik dan Mengembangkan Moral Anak. Bandung: IramaWidya

Sari, A dkk. 2010. Pengaruh Pola Komunikasi Keluarga dalam Fungsi Sosialisasi Keluarga terhadap Perkembangan Anak. Jurnal Komunikasi Pembangunan Vol 08 No 2 Juli 2010

Setyowati, Yuli. 2005. Pola Komunikasi Keluarga dan Perkembangan Emosi Anak. Jurnal Ilmu Komunikasi Volume 2 No 1 Juni 2005

Susanto Ahmad, 2011. Perkembangan Anak Usia Dini, Pengantar Dalam

Berbagai Aspeknya. Jakarta:Kencana Prenada Media Group

Wahyudi, Deddy. 2011. Pembelajaran IPS Berbasis Kecerdasan Intrapersonal Interpersonal dan Eksistensial. Jurnal Penelitian 


\section{Pendidikan Edisi Khusus No 1}

Agustus 2011

Wijaya, A.W. 2000. Ilmu Komunikasi

Pengantar Studi. Jakarta:

Rineka Cipta

Yusuf, Syamsu L N. (2011). Psikologi

Perkembangan Anak dan

Remaja. Bandung: Remaja

Rosda Karya 